\title{
EFFECT OF GENOTYPE AND PHYSIOLOGICAL STUTES ON DOE WEIGHT AND SOME BLOOD INDICATORS
}

\author{
W.H. Kishk, E.G. Ahmed and A.M. Abdel-Ghany \\ Animal Production Department, Faculty of Agriculture, Suez Canal University, Ismailia, Egypt \\ SUMMARY
}

Blood picture of two breeds group of randomly chosen contemporary rabbit does $(n=37 ; 24$ of Californian and 13 of White New Zealand) was studied. The aim was to study the effect of genotype and reproductive status (pregnant or non-pregnant) on doe weights and doe blood picture (red blood cell and white blood cell counts as well as Hemoglobin content). Results showed that there were no significant differences in blood picture and doe weight due to genotype while there was significant difference in doe weight attributed to doe reproductive status. Finally and apart of breed effect, it could be concluded that doe weight can be taken as an indicator for expected doe physiological condition and blood parameters.

\section{Keywords: genotype, physiological, Doe, reproductive statue}

\section{INTRODUCTION}

Doe weight and hematological profile are good indications of the metabolic status of rabbits (Ahmed et al., 2014). There are abundance of research work on describing haematological parameters in relation to physiological rabbit status (Dontas et al., 2011 \& Ebeid et al., 2012). These experiments indicated that feed restriction can significantly reduce erythrocytes numbers and haemoglobin concentration while MCV (mean corpuscles volume) was significantly increased (Ebeid et al., 2012). Doe weight is directly affected by nutritional level; hence it may be taken as an indirect indicator for doe blood picture. Likewise, reproductive status can proportionately affect doe weight and/or doe blood picture especially in the second half of pregnancy period as pointed out also in mammals by many researchers (Peck and Arias 1979; Lurie, 1993 \& Rastogi et al., 2003). It is likely that doe breed can influence fatting rate, doe weight concurrently together with blood picture or separately. Biochemical characterization of rabbit blood picture will help in better understanding of rabbit in relation to growth, meat, fur and wool quality. An attempt was made in present work to study the blood biochemical profile in doe rabbit under different physiological status of pregnancy.

Therefore, the objective of this study was to find out the effect of doe genotype and reproductive status on doe weight and blood picture.

\section{MATERIALS AND METHODS}

A total of 37 multiparous doe rabbits (24 of Californian, (Cal) and 13 of White New Zealand, NZW) of two breeds were used in this investigation. Does were part of the flock of the
Experimental Rabbitry Farm; Faculty of Agriculture; Suez Canal University; Ismailia; Egypt. This experiment was carried out during the period of winter season of 2011. Does were housed in a metal separated cages with an attached nest for kits nursing. Does were housed in individual cages provided with nest boxes for kits nursing, feeders and automatic drinkers. All animals were contemporaneous and have been subjected to the same managerial and environmental conditions. Rabbits were fed on a commercial pelleted ration containing approximately $16.1 \%$ protein, $2.39 \%$ crude fat, $12.8 \%$ crude fiber and $2500 \mathrm{kcal} \mathrm{DE} / \mathrm{kg}$ diet, digestible energy. Feed and water were provided ad libitum. At the beginning of the experimental work does were randomly ranked into groups of five to six according to the available numbers, to each a buck of the same breed was assigned as a rule indiscriminately, with just a restriction of avoiding parent-offspring and sib mating. Mating was held approximately 7 days after kindling at when does were transferred to the cage of its assigned buck to be mated. Pregnancy was determined by palpation 14 days following mating. Females that failed to conceive were returned to the same assigned buck to be re-bred. All thorough the entire period of the study, each buck was allowed to sire all his litters from its own assigned female group. Does which failed to progressively conceive more than twice were culled. Light was allowed 14-16 hr. per day using ordinary 40 watts light bulb lamps distributed evenly to provide an approximately light intensity of 4.5 watt/M.

Blood samples were obtained from each doe, in heparinized tubes, from the ear vein. Collection of the blood samples was attained at 14 day after mating between 8:00-10:00 am to avoid diurnal variation in the blood picture as stated by Thompson and Proctor (1984). Red blood cells (RBCs) and white blood cells 
(WBCs) were counted in fresh blood samples using hemocytometer. Hemoglobin ( $\mathrm{Hb})$ concentration was determined using a hemometer as the method described by Tietz (1982). Each doe was weighed before blood sample collection and also was palpated at 14 day after mating to determine reproductive status.

Data of NZW and Cal rabbit does were analyzed using SAS (2003). The linear fixed model adopted for the analysis comprised the effects of weight and age of doe at kindling. The basic form of the general linear mathematical model is: $\quad \mathrm{Y}=\mathrm{X} \beta+\mathrm{e}$
Where

$\mathrm{Y}=(\mathrm{n} \times 1)$ an observational column vector of the rabbit doe trait data.

$\mathrm{X}=$ Incidence matrix of zeros and ones which relating records to the appropriate fixed effects.

$\beta=\left(\begin{array}{lll}1 & \mathrm{x} & \mathrm{n}\end{array}\right)$ the raw vector of unknown fixed effects (i.e. breed and reproductive status).

$\mathrm{e}=$ the vector of random error.

\section{RESULTS AND DISCUSSIONS}

Least squares means of doe weight as regards to the effect of doe breed and physiological status are presented in Table (1).

Table 1. LSM $( \pm$ SE) of doe body weight as affected by rabbit doe breeds and doe physiological status

\begin{tabular}{|c|c|c|c|c|}
\hline \multirow{2}{*}{ Parameter } & \multicolumn{2}{|c|}{ Breed } & \multicolumn{2}{|c|}{ Physiological status } \\
\hline & Californian & New Zealand & Pregnant & Non-pregnant \\
\hline$\frac{\text { Doe weight }}{\text { significance }}$ & \multicolumn{2}{|c|}{$\underline{\mathrm{Ns}}$} & \multicolumn{2}{|c|}{$\mathrm{P}<0.05$} \\
\hline $\begin{array}{l}\text { Ls-Mean (g.) } \\
\pm \text { SE }\end{array}$ & $\begin{array}{l}3212.5 \\
\pm 62.79\end{array}$ & $\begin{array}{c}3250.0 \\
\pm 115.19\end{array}$ & $\begin{array}{c}\text { 3386.11 }^{\mathrm{a}} \\
\pm 65.41\end{array}$ & $\begin{array}{r}\mathbf{3 0 7 4 . 6 8}^{\mathrm{b}} \\
\pm 77.36\end{array}$ \\
\hline
\end{tabular}

Means within same row with different superscripts differ significantly $(\mathrm{P}<0.05)$ using Duncan's Multiple range test.; ns $=$ Not Significant.

Results of the analysis of variance of this experiment showed no significant differences in doe weight due to effect of doe breed. This could be a resultant from the high values within breed variability in doe weights. On the other hand, doe physiological status had significant effect $(\mathrm{P} \leq 0.05)$ on doe weights, Table $(1)$.

Pregnancy can affect doe weight especially in the case of high litter size rates. Where there is an increase in embryos' and embryonic fluid weights as well as the enormous increase in the uterine horns size and weight.

Observations on the effect of doe breed and physiological status on doe counts of RBCs and WBCs and HB are presented in Table (2).

These results showed that there were no significant differences in doe blood picture due to doe breed and/or doe physiological status. Also, there was insignificant decrease in counts of RBCs and WBCs during the physiological status of pregnancy. As ancient as in the first half of the $19^{\text {th }}$ century, Zarrow and Zarrow (1953) and Horger and Zarrow (1957) described the anemia of pregnancy in rabbits. Roy et al. (1965) described briefly changes (decreasing numbers) in the red blood cell count in goats during pregnancy, parturition and post-parturition periods. Similar observations were made by Andersen and Gee (1958), and Tietz, Jr et al. (1967) on dogs and Mizoguchi et al. (2010) on rabbits. However, the present results may reveal that, though lack significance, this picture of anemia in rabbits may not be possibly restricted to the counts of RBC's but it may include WBC's.

These previous observations (decreasing numbers of RBCs and WBCs) can be describe further by the within breed changes in blood picture during pregnancy in rabbits as shown in Table (3). Where RBCs, WBCs, Hb and doe weight had changed according to physiological status in both doe breeds. While, Cal does revealed insignificantly increase in RBC's count from $4.54 \pm 0.35$ to $4.59 \pm 0.36 \times 10^{6} /$ microliter during pregnancy, same parameter has a pronounced significant decreasing in NZW ones from $5.39 \pm 0.40$ to $4.60 \pm 0.46 \times 10^{6} /$ microliter during pregnancy (Table 3). However during pregnancy, WBC counts insignificantly decreased in both doe breeds. Nevertheless, hemoglobin concentration as a criterion was not greatly affected by physiological status in both breeds. Blood picture acts a key role in homeostasis balance as discussed by many authors (Brecher and Stohlman, Jr. 1959; Miale, 1967 \& Kaneko, et al., 2008). In which blood could be considered as an essential components of the body and relays on nutrition in its formation. Iron is a major component in $\mathrm{Hb}$ formation as for RBCs constitution. On the other hand WBCs correlated directly to immune system of animal body. Where could be responsible for the animal health and disease defense. Therefore, blood picture correlated to internal doe environment and homeostasis condition which enable rabbit doe for maximum production. 
Table 2. LSM \pm SE of doe blood indicators as affected by rabbit doe breeds (Californian $\& W h i t e$ New Zealand) and doe reproductive physiological status

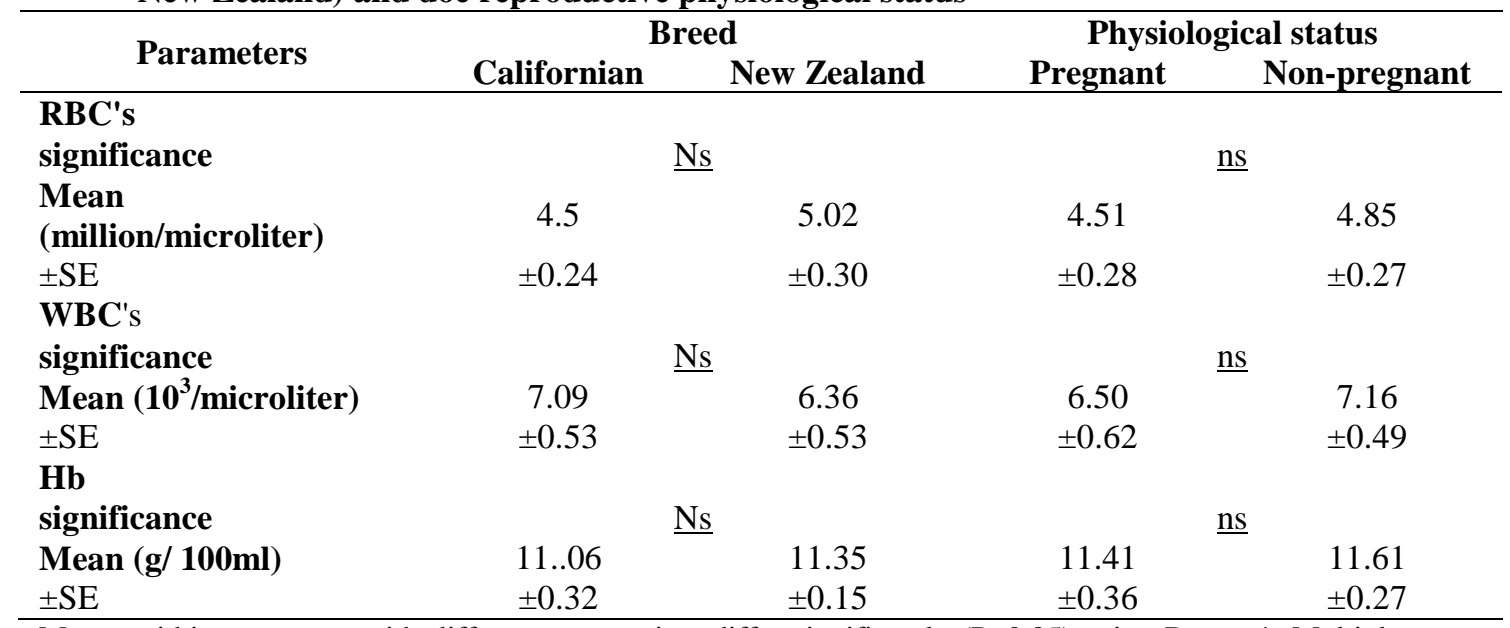

Means within same row with different superscripts differ significantly $(\mathrm{P}<0.05)$ using Duncan's Multiple range test.; ns $=$ Not Significant

Table 3. Least squares means $\pm \mathrm{SE}$ of doe weight, counts $\mathrm{RBC}$ 's and WBC's, Haempglobin (Hb) for Californian \&White New Zealand rabbit breeds as affectd by reproductive physiological status

\begin{tabular}{|c|c|c|c|c|}
\hline 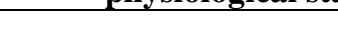 & \multicolumn{4}{|c|}{ Breed } \\
\hline & \multicolumn{2}{|c|}{ Californian } & \multicolumn{2}{|c|}{ White New Zealand } \\
\hline & Pregnant & Non-pregnant & Pregnant & Non-pregnant \\
\hline Doe weight & \multicolumn{4}{|c|}{ Interaction significant $\mathrm{P}<0.05$} \\
\hline mean $(\mathrm{g})$ & $3341.67^{\mathrm{a}}$ & $3083.33^{\mathrm{b}}$ & $3475.00^{\mathrm{a}}$ & $3075.14^{\mathrm{b}}$ \\
\hline$\pm \mathrm{SE}$ & 85.02 & 78.9 & 97.25 & 170.58 \\
\hline $\mathrm{RBC}$ & \multicolumn{4}{|c|}{ Interaction not significant } \\
\hline $\begin{array}{l}\text { mean } \\
\text { (million/microliter) }\end{array}$ & $4.59^{\mathrm{b}}$ & $4.54^{\mathrm{b}}$ & $4.60^{\mathrm{b}}$ & $5.39^{\mathrm{a}}$ \\
\hline$\pm \mathrm{SE}$ & \pm 0.36 & \pm 0.35 & \pm 0.46 & \pm 0.40 \\
\hline WBC & \multicolumn{4}{|c|}{ Interaction not significant } \\
\hline mean $(103 /$ microliter $)$ & 6.82 & 7.37 & 5.85 & 6.80 \\
\hline$\pm \mathrm{SE}$ & \pm 0.85 & \pm 0.68 & \pm 0.81 & \pm 0.71 \\
\hline $\mathbf{H b}$ & \multicolumn{4}{|c|}{ Interaction not significant } \\
\hline mean & 11.35 & 11.87 & 11.41 & 11.20 \\
\hline$(\mathrm{g} / 100 \mathrm{ml}) \pm \mathrm{SE}$ & \pm 0.52 & \pm 0.36 & \pm 0.40 & \pm 0.40 \\
\hline
\end{tabular}

Means within same row with different superscripts differ significantly $(\mathrm{P}<0.05)$ using Duncan's Multiple range test..; ns = Not Significant

\section{CONCLUSIONS}

This study, and as a conclusion, could put some emphasis on the effect of doe weight and hematological indicators as tools for evaluating internal physiological condition of the pregnant does, especially during first half of pregnancy. On the other hand and from a practical point of view, doe weighting is practiced in Rabbitry as a routine work for doe follow up and recording (Ahmed et al., 2014). In addition, the only blood parameter that seemingly has been affected by the physiological status from those studied ones, is the RBC's counts. Results also reveal that rabbit does of both breeds doesn't suffer from the so called pregnancy anemia at least after 14 days of being pregnant. Moreover, the blood picture and its sensitivity to physiological status, though need further studies, may differ from one breed to another.

\section{REFERENCES}

Ahmed, E.G.; W. H. Kishk, N. S. Hassan, A. M. Abdel-Ghany, 2014. Litter and Mean Bunny Weights as Affected by New Zealand White Rabbit Doe Age / Weight at kindling under Semi-Arid Environment of Ismailia Province. $7^{\text {th }}$ International Conference on Rabbit Production in Hot Climate. 8-12 September, Marsa Alam, Red Sea, Egypt.

Anderson, A.C. and W. Gee, 1958. Normal blood values in the Beagle. Vet. Med. 53, 135-138.

Brecher, G. and. F. Jr. Stohlman, 1959. Humoral factors in erythropoiesis, p. 110132. In L.M. 
Tocantins [ed.] Progress in Hematology. Vol. 2. Grune \& Stratton, New York.

Ebeid, T., E. Tumova and Z. Volek, 2012. Effect of a one week intensive feed restriction in the growing rabbit: Part1-Performance and blood biochemical parameters.World Rabbit Science Association, Proceedings $10^{\text {th }}$ World Rabbit Congress - September 3 - 6, 2012Sharm El- Sheikh -Egypt, 607 - 611.

Horger, L. M. and M. X. Zarrow, 1957. Certain endocrine aspects of the anemia of pregnancy in the rabbit. Am. J. Physiol., 189, 407-411, 1957.

Kaneko, J.J., J.W. Harvey and M.L. Bruss, 2008. Clinical biochemistry of domestic animals. 6th ed. San Diego, CA: Academic Press, 493, 889-895.

Lurie, S., 1993. Changes in age distribution of erythrocytes during pregnancy, A longitudinal study. Gynaecol. Obstet. Invest. 36, 141-144.

Miale, B., 1967. Laboratory medicinehematology, $3^{\text {rd }}$ ed. The C. V. Mosby Company, St. Louis.

Peck, T.M. and F. Arias, 1979. Hematologic changes associated with pregnancy. Clin. Obstet. Gynaecol. 22, 485-498.

Rastogi A., N. Dutta and K. Sharma, 2003. Effect of Strategic Feed Supplementation during Gestation on Intake, Bloodbiochemical Profile and Reproductive Performance of Goats. Asian-Aust. J. Anim. Sci. Vol 16, No. 12: 17 25-1731.

Roy, A., K. L. Sahni and I. C. Dutta, 1965. Studies on certain aspects of sheep and goat husbandry. VII variation in blood corpuscles of sheep and goat during different seasons, pregnancy, parturition and post parturition period. Indian J. Vet. Sci. 35:24-32.

SAS, 2003. Statistical Analysis System Institute. SAS' Procedure Guide: release 9.3 SAS Instute Inc., Cary Nc, USA.

Thompson, A. and Proctor, 1984. A concise textbook of hematology. $6^{\text {th }}$ Edition, Published by Lippincott, Williams \& Wilkins.

Tietz W.J., M.M. Benjamin and G.M. Angleton ,1967. Anemia and cholesterolemia during estrus and pregnancy in the Beagle. Am J Physiol. Mar; 212(3):693-697.

Tietz, N. W., 1982. Fundamental of clinical chemistry. Edition by Norbert Sanrders, Company, Philadelphia, USA.

Zarrow, M. X. and I. G. Zarrow, 1953. Anemia in the rabbit during pregnancy and following treatment with water soluble ovarian extracts. Endocrinology 52: 424-435.

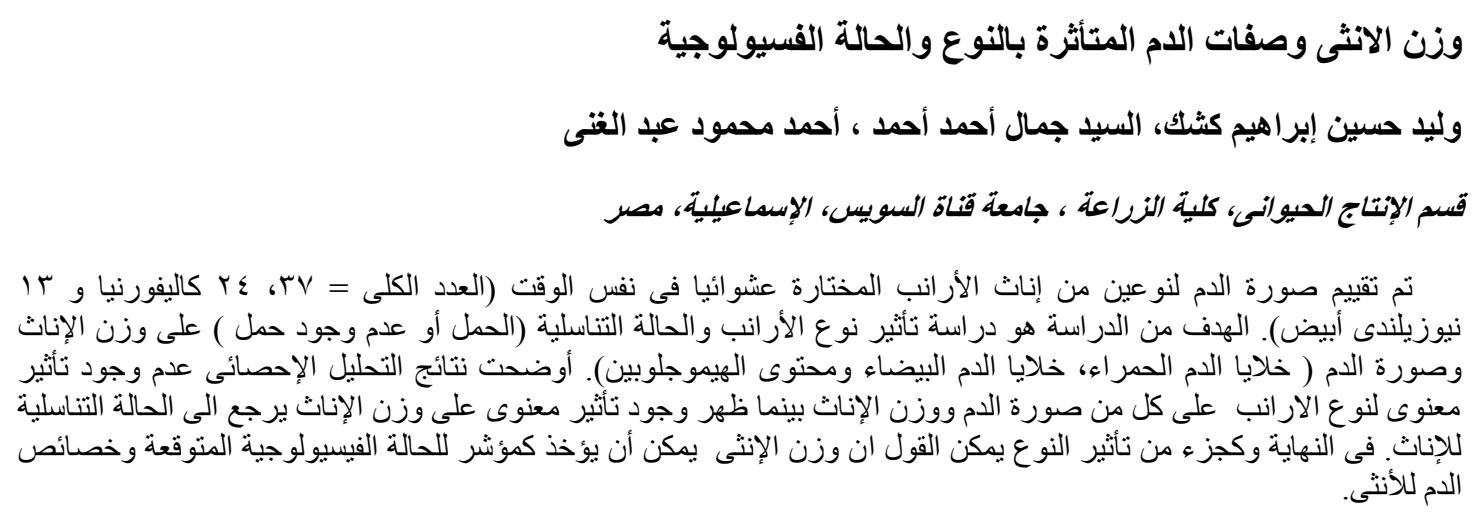

